地域地区や都市基盤が新築建築物の敷地面積に与える影響の分析

大場＼cjkstart亨、田草川信慈、鈴木義昌

\title{
The Effect of Zoning Systems and That of Urban Infrastructures on the Areas of Lots on which New Buildings Are Constructed
}

\author{
Tohru OHBA, Shinji TAKUSAGAWA and Yoshimasa SUZUKI
}

\begin{abstract}
This paper aims to analyze the effect of various zoning systems and urban infrastructures on lot areas. First, the hypothesis that the population distribution of lot areas is the logarithmic normal distribution is tested by the goodness-of-fit test. Second, the difference of cumulative relative frquency distribution between zoning systems is tested with the Kolmogorov-Smirnov test. Third, the compound effect of zoning systems and urban infrastructures is analyzed with the type 1 quantification method. It reveals that lot areas of housing and apartment housing are not much affected by zoning systems and the distance to the nearest railway station,but those of commercial buildings are much affected.
\end{abstract}

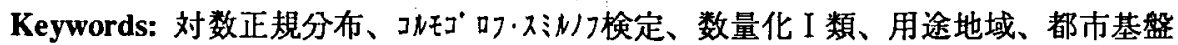

1.はじめに

本研究の目的は、地域地区や都市基盤施設が敷地 面積に与える影響を分析することにある。今後の地 域 地区指定のありかたや敷地の細分化の防止を検 討する上で、これらが敷地面積に与える影隌を分析 することは有益であると考える。

建築物の敷地面積に関しては既に多くの研究が見 られる。石坂(1984)は、成熟型市街地とスプロール 型市街地内では一戸長屋住宅の敷地規模の分布が対 数正規分布に近似されることを明らかにしている。 横屋、光吉、萩島、金(1984)は、福岡市における新 築建築物の立地に与えた新旧用途地域の指定効果の 分析を行い、建築物の建ぺい率や容積率に対しては 用途地域の要因効果を認めたものの、敷地面積に対 してはその要因効果を積極的には認めていない。ま た、マニルザマン、浅見、岡部(1994)は、単に敷地 面積のみでなく、敷地の形状に関する指標を提案し、 これを実際の市街地に適用した例を報告している。

大場： 7272 千葉県市川市八幡1-1-1 市川市建設局都 都市計画部 Tel. 0473-34-1111 .ext. 3317. Citty Planning Department, Ichikawa City Office, 1-1-1 Yahata, Ichikawa-shi, Chiba 272
このように、市街地の類型、用途地域、敷地の形 状などが敷地規模に対する影響要因として考えられ てきた。しかし、このほかにも様々な要因が敷地面 積に影響を与えていると考えられる。本稿では、新 築の建築物の敷地面積に影響を与えた要因として、 各種の地域地区と都市基盤施設を考え、建築物主要 用途毎に分析を行う。地域地区として都市計画法第 8 条などの法令に定める地域地区のうち用途地域の みでなく、高度地区、風致地区、宅地造成工事規制 区域、土地区画整理事業施行区域を考える。また、 都市基盤施設が敷地面積に与える影響要团として各 建築物から最寄りの駅までの距離を考える。

まず、第 3 節で調查対象とした建築物の敷地面積 の分布の特徴を明らかにする。次いで第 4 節で、地 域地区毎の敷地面積の累積相対度数分布についてコ ルモコロフ・スミルノフ検定を行った結果を示す。

第 5 節では、最奇り駅まで距離と敷地面積の相関 係数を算出する。第 6 節で、数量化 I 類分析により、 地域地区や都市基盤施設が敷地面積に与える影響を 分析する。 
表 1 建筑物主要用途の分類及び敷地面皘 $\left(\mathrm{m}^{2}\right)$ の基本特計量

\begin{tabular}{|c|c|c|c|c|}
\hline 建策物主要用途 & 施設の分類 & 度数 & 平均値 & 標準偏差 \\
\hline 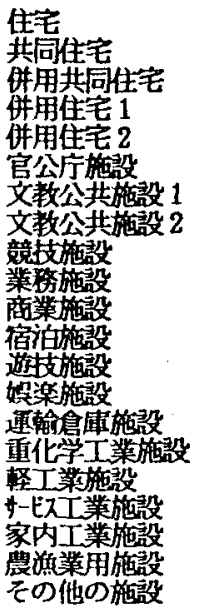 & 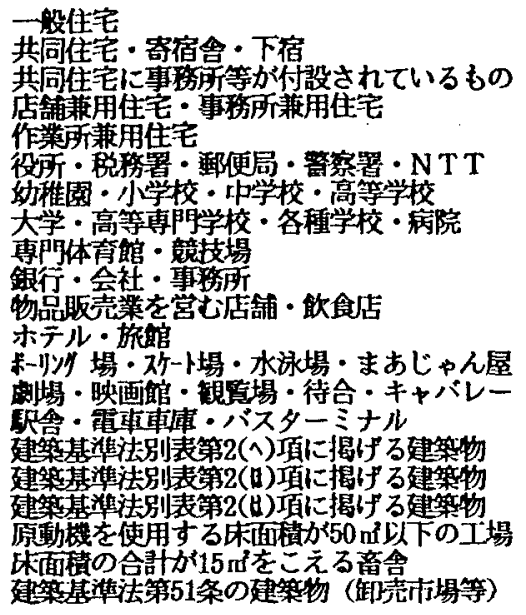 & $\begin{array}{r}2025 \\
905 \\
119 \\
156 \\
12 \\
1 \\
6 \\
1 \\
0 \\
64 \\
59 \\
1 \\
5 \\
1 \\
38 \\
3 \\
3 \\
13 \\
1 \\
1 \\
0\end{array}$ & $\begin{array}{l}168.4 \\
403.0 \\
393.3 \\
196.8 \\
260.4\end{array}$ & $\begin{array}{l}151.7 \\
490.1 \\
410.4 \\
230.9 \\
239.4\end{array}$ \\
\hline \multicolumn{2}{|l|}{ 全建物主要用狳椐 } & 3414 & 287.2 & 1531.1 \\
\hline
\end{tabular}

\section{3. 敷地面積の分布}

調查対象建筑物の度数、敷地面積 の平均値及び標準偏差を建築物主要 用途別に算出した結果を表】に示す (1)。住宅系の建物主要用途で度数 が多く、とりわけ住宅の度数が多 かった。調査対象建築物全体での敷 地面積の平均值は 287.2 平方メート ル、標準偏差は1531.1平方メートル であった。

次に敷地面積の分布の特性につい て検討する。前述のように、既存の 一戸長屋住宅の敷地規模の分布が対 数正規分布に近似されることが石坂 (1984)により明らかにされている。このことが同様

\section{2. 分析の方法}

調査対象としたのは、千葉県市川市の市街化区域 内において 1990 (平成 2 ) 年 4 月から 1992 (平成 4) 年 3 月までの 2 年間に建築確認申請された新築 の建築物3414棟である。デジタイザーを用いて、こ れらの位置座標をポイントデータとて入力した。 さらに、建築計画概要書に記載された建築物主要用 途を表 1 に示す 21 種類に分類したものと敷地面積を これらの建築物ポイントに属性として付加した。

一方、用途地域、高度地区、風致地区、宅地造成 工事規制区域、土地区画整理事業施行区域をそれぞ れボリゴンデータで入力した。これらの地域地区ポ リゴンと建築物ポイントとをオーバーレイし、各建 笑物がどの地域地区に属しているかを示すデー夕を 建築物ポイントの属性として取得した。

さらに、各駅の位置を示すポイントと各建築物ポ イントとの距離を計測し、これらのうち各建築物に とって最寄りである駅までの距離を建築物ポイント の属性として取得した。

以上の操作には地理情報システムソフトゥェア ARC/INFO Ver5.0.1を用い，度数分布の算出、検定、 相関係数の算出、数量化 I 類分析を行うにはLotus 123 for Sun Ver1.0を用いた。
に新築の建筑物にも見られるか、また、住宅以外の 建築物主要用途にも見られるかについて検討する。

対数正規分布への適合度を検討するため、度数が 30以上であった建築物主要用途の各建築物の敷地面 積を自然対数変換し、正規分布の適合に関するカイ 2 乗量、䟚度、尖度を算出した。カイ 2 乗量は、自 然対数変換した敷地面積を 8 区間に区切って、次式 により算出された。

$$
X_{0}^{2}=\sum_{i=1}^{8} \frac{\left(x_{i}-e_{i}\right)^{2}}{e_{i}}
$$

ただし $\mathrm{i}$ は自然対数变換した敷地面積の階級、 $\mathrm{x}_{\mathrm{i}}$ は 階級 $\mathrm{i}$ の観察度数、 $e_{i}$ は、仮説「敷地面積の分布は 対数正規分布に従う。が成立すると仮定した場合の 階級 $\mathrm{i}$ の期待度数である。また、䄳度 $\sqrt{\beta}$ 、尖度 $\beta_{2}$ は、次式により算出されたものである。

$$
\begin{array}{r}
\sqrt{\beta_{1}}=\frac{\sum_{j=1}^{n}\left(x_{j}-\bar{x}\right)^{3}}{n s^{3}} \\
\beta_{2}=\frac{\sum_{j=1}^{n}\left(x_{j}-\bar{x}\right)^{4}}{n s^{4}}
\end{array}
$$

ただし $\mathrm{x}_{\mathrm{j}}$ は自然対数変換した敷地面積、 $\bar{x}$ は $\mathrm{x}_{\mathrm{j}}$ の平 均、sは $x_{j}$ の標準偏差である。 
こうして算出された結果を表 2 に示す。仮説「敷 地面皘の分布は対数正規分布に従う。」をカイ 2 乗 適合度検定により有意水準 $5 \%$ で菓却することがで きなかった建築物主要用途は、併用共同住宅、併用 住宅 1、業務施設、運輸倉庫施設であった。一方、 有意水準 $5 \%$ 以下で仮説が亲却された建築物主要用 途は、住宅、共同住宅及び商業施設であった。

表 2 自然対数変換データの正規分布への適合性

\begin{tabular}{|c|c|c|c|c|}
\hline 建築物主要用途 & $x_{0}{ }^{2}$ & 意水準 & 跐度 & 尖度 \\
\hline 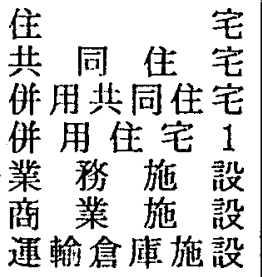 & $\begin{array}{r}18.82 \\
69.92 \\
5.81 \\
5.69 \\
5.29 \\
22.17 \\
8.42\end{array}$ & $\begin{array}{l}0.5 \% \\
0.1 \%\end{array}$ & $\begin{array}{l}0.289 \\
0.670 \\
0.380 \\
0.683 \\
0.038 \\
2.441 \\
0.056\end{array}$ & $\begin{array}{r}3.337 \\
4.139 \\
2.962 \\
4.004 \\
3.473 \\
14.079 \\
3.058\end{array}$ \\
\hline
\end{tabular}

住宅の敷地面積の自然対数变換データについて歪 度または尖度による正規分布への適合性検定を行う と、やはり仮説は、歪度・尖度ともに有意水準 $1 \%$ で棄却される。自然対数变換を行ってもなお敷地面 積の分布の歪度は正の值を示しており、図 1 の度数 分布多角形からも観察度数が対数正規分布の期待度 数よりもやや正に昰んでいる様子が読み取れる。こ のように、既存の住宅の敷地面積の分布が対数正規 分布に近似されることを石坂(1984)は明らかにした が、新筑のそれは対数正規分布の期待度数よりもや や正に歪んでいることが本稿では明らかになった。 市川市のような成熟型市街地においては新筑の住宅 の敷地規模の分布は既存のそれと同じであると石坂 は仮定していたが、この結果からは成熟型市街地に おいても住宅が新築される際に敷地の細分化が進ん でいる可能性が示唆される。今後、敷地の細分化の 特徴を明らかにするために、既存と新筑の住宅の敷 地面積をより詳細に分析する必要がある。

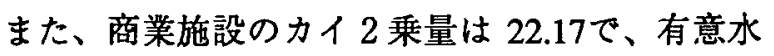
準 $0.1 \%$ で仮説が裹却される（表 2 ）。自然对数变換 された敷地面積の分布の尖度は 14.079 と著しく高く、 図 2 の度数多角形からも、原データの敷地面積 150 平方メートルから 350 平方メートルを中心に度数が、
敷地面積が極めて大きいために図 2 に表示しきれな かった 3 棟の商業施設が平均值や標準偏差を大きく している（表1）。このように、商業施設では大多 数の小規模施設とごく少数の大規模な商業施設が建 筑確認申請されており、市川市における商業施設の 敷地面積は、他の建築物主要用途のそれと比べて特 異な分布を示している。

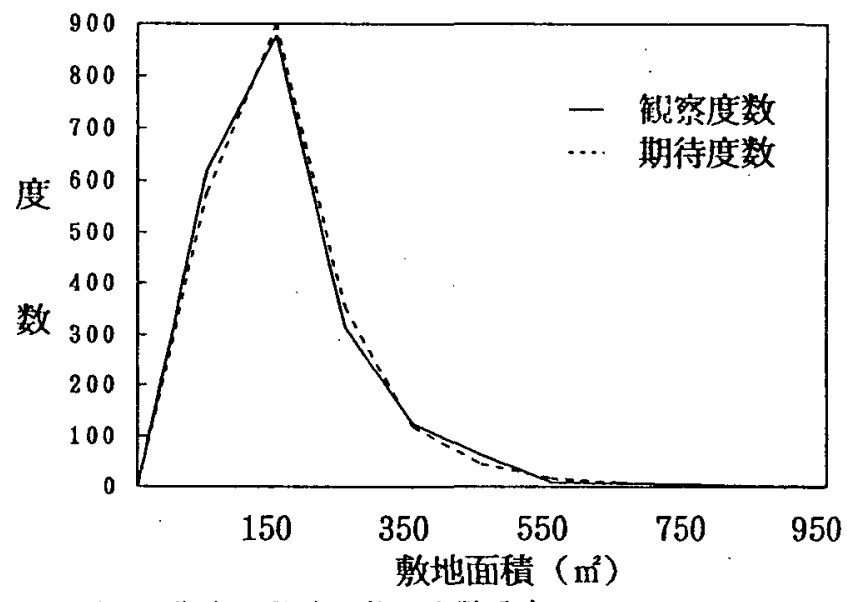

図 1 住宅の敷地面積の度数分布

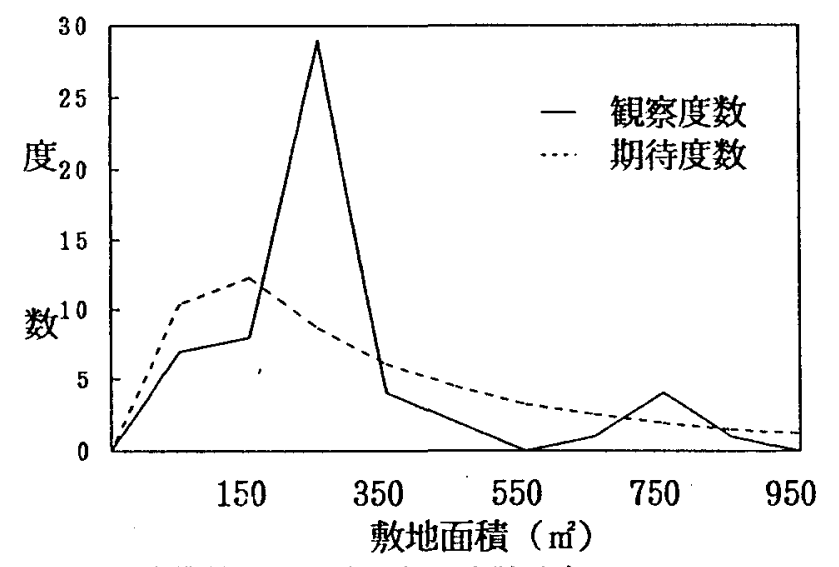

図 2 商業施設の敷地面積の度数分布

\section{4. 用途地域、高度地区別の敷地面積の累積相対 度数分布}

次に敷地面積を 100 平方メートル毎に区切って算 出した累積相対度数分布に建築物主要用途、用途地 域、高度地区の種別により相違が見られるかについ て、コルモゴロフ・スミルノフ検定により検討する。 第 3 節の結果から、母集団の分布に特定の分布を仮 定しないノンパラメトリックな手法の一つであるコ ルモコロフ・スミルノフ検定を採用することとした。 建築確認申請件数が少なかった近瞵商業地域と商 
業地域については商業系用途地域として分類を一つ にし、同样に準工業地域、工業地域、工業尃用地域 については工業系用途地域として分類を一つにした。

すべての対照群間で仮説「一方の群の母集団の敷 地嫢模は他方の群のそれと同じである。」について 片伹検定を行った。また、対照群の双方で度数が40 以上であったときは、仮説「2つの地域地区の母集 団の分布は同じである。」について両側検定も行っ た。片側検定で仮説が亲却されたものと両側検定の 結果のすべてを表 3 に示す。表 3 で、累積相対度数 の最大差（ $\mathrm{a}$ 群の累積相対度数一 $\mathrm{b}$ 群の累積相対度 数）が正の値であるときは、a 群での累積相対度数 が高く、a 群での敷地規模のほうが小さいかどうか について片側検定を行ったことを示している。

住宅では、第 1 種住居専用地域と第 2 種住居専用 地域間、第 1 種住居専用地域と住居地域間で片側検 定の仮説及び両側検定の仮説が $0.1 \%$ の有意水準で 菓却された。いずれの場合も敷地面皘 100 平方メー トル以下の階級で累皘相対度数の差が最大となって おり、第 1 種住居専用地域の累積相対度数のほうが 低い数值になっていた。用途地域別の住宅の敷地面 積の累積相対度数分布を図 3 に示す。第 2 種住居専
用地域及び住居地域の累積相対度数と比べて、第 1 種住居専用地域のそれは敷地面積 100 平方メートル 以下の階級でかなり低い数值になっていることが読 み取れる。このことは、面積 100 平方メートル以下 の狭小な敷地の相対度数が第 1 種住居専用地域内で 少ないことを示している。建ぺい率の最高限度が60 \%以下の制限である第 2 種住居専用地域や住居地域 内と比べて、それが $40 \%$ 以下や50\%以下に制限され ている第 1 種住居専用地域内の狭小な敷地では、建 築面積を僅かしかとれないこととなるため、良好な 居住空間を有する住宅を建築しにくいためと考えら れる。同様の傾向は、共同住宅における第 1 種住居 専用地域と住居地域間、第 1 種住居専用地域と商業 系用途地域間、併用住宅 1 における第 1 種住居専用 地域と第 2 種住居専用地域間、第 1 種住居専用地域 と商業系用途地域間においても見られた（表 3 ）。

共同住宅では、第 2 種住居専用地域と工業系用途 地域、商業系用途地域と工業系用途地域間に片側検 定における有意な差が見られた。図 4 は、用途地域 別の共同住宅の敷地面積の累積相対度数分布である。 工業系用途地域内の共同住宅の敷地面積は、他の用 途地域内におけるそれよりも大きくなっていること

表 3 用途地域・高度地区毎の累積相対度数分布に関するコルモゴロフ・スミルノフ検定䊅果

\begin{tabular}{|c|c|c|c|c|c|c|c|c|c|}
\hline \multirow{2}{*}{$\begin{array}{c}\text { 建案物主要 } \\
\text { 用 途 }\end{array}$} & \multicolumn{2}{|c|}{ 地 域 地 区 } & \multicolumn{2}{|c|}{ 度数 } & \multicolumn{2}{|c|}{ 累皘相対度数 } & \multirow{2}{*}{$\begin{array}{l}\text { 雨側檢 } \\
\text { 定結果 }\end{array}$} & \multirow{2}{*}{$x_{0}^{2}$} & \multirow{2}{*}{$\begin{array}{l}\text { 片㑡検 } \\
\text { 定結果 } \\
\end{array}$} \\
\hline & $\mathbf{a}$ & $\mathrm{b}$ & $a$ & $\mathrm{~b}$ & 最大差a-b & 階䄲 $\mathrm{m}^{\prime \prime}$ & & & \\
\hline 宅 & 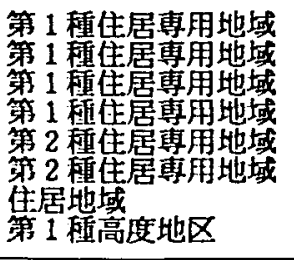 & 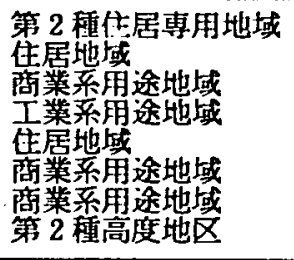 & $\begin{array}{r}1231 \\
1231 \\
1231 \\
1231 \\
323 \\
323 \\
408 \\
574\end{array}$ & $\begin{array}{r}323 \\
408 \\
49 \\
14 \\
408 \\
49 \\
49 \\
195\end{array}$ & $\begin{array}{r}-0.1998 \\
-0.2064 \\
-0.0991 \\
-0.3440 \\
-0.0183 \\
0.1007 \\
0.1073 \\
-0.0572\end{array}$ & $\begin{aligned} 0<< & =100 \\
0<< & =100 \\
0< & =100 \\
0< & <=100 \\
100<< & =200 \\
0<< & =100 \\
0<< & =100 \\
0<< & =100\end{aligned}$ & $\begin{array}{l}0.18 \\
0.18 \\
-\end{array}$ & $\begin{array}{r}40.8512 \\
52.2007 \\
1.8502 \\
6.5512 \\
0.2420 \\
1.7262 \\
2.0144 \\
1.9023\end{array}$ & $\begin{array}{l}0.18 \\
0.18 \\
5.08\end{array}$ \\
\hline 共同 住 宅 & 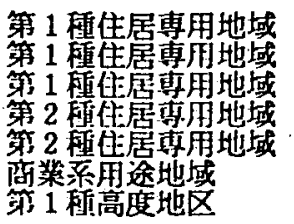 & 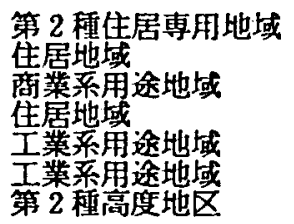 & $\begin{array}{r}259 \\
259 \\
259 \\
286 \\
286 \\
22 \\
408\end{array}$ & $\begin{array}{r}286 \\
308 \\
22 \\
308 \\
30 \\
30 \\
227\end{array}$ & $\begin{array}{r}-0.0599 \\
-0.1271 \\
-0.2829 \\
-0.0784 \\
0.2746 \\
0.4121 \\
0.1248\end{array}$ & $\begin{array}{l}200<<=300 \\
100<<=200 \\
100<<=200 \\
100<<=200 \\
300<<=400 \\
100<<=200 \\
200<<=300\end{array}$ & $\begin{array}{l}2.5 \% \\
- \\
2.5 \%\end{array}$ & $\begin{array}{l}\text { 1. } 9515 \\
9.0857 \\
6.4917 \\
3.6481 \\
8.1891 \\
8.6228 \\
9.0796\end{array}$ & $\begin{array}{l}2.0 \% \\
5.08 \\
2.08 \\
2.08 \\
2.08\end{array}$ \\
\hline 作用北同住宅 & 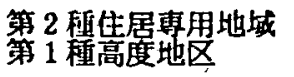 & 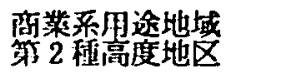 & $\begin{array}{l}31 \\
47\end{array}$ & $\begin{array}{l}16 \\
53\end{array}$ & $\begin{array}{l}0.3992 \\
0.0935\end{array}$ & $\begin{array}{l}200<<=300 \\
200<<=300\end{array}$ & - & $\begin{array}{l}6.7268 \\
0.8718\end{array}$ & $5.0 x$ \\
\hline 垪用住宅 1 & 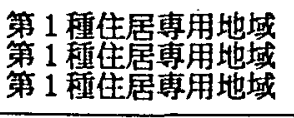 & 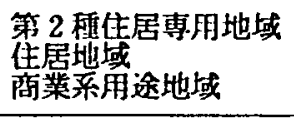 & $\begin{array}{l}52 \\
52 \\
52\end{array}$ & $\begin{array}{l}38 \\
42 \\
22 \\
\end{array}$ & $\begin{array}{l}-0.3320 \\
-0.2418 \\
-0.4301\end{array}$ & $\begin{array}{l}0<<=100 \\
0<<=100 \\
0<<=100\end{array}$ & - & $\begin{array}{r}9.6792 \\
5.4318 \\
11.4375 \\
\end{array}$ & $\begin{array}{l}1.0 x \\
0.5 x\end{array}$ \\
\hline 業 弱 施 設 & 陌業系用途地域 & 工業系用途地域 & 17 & 11 & 0.6417 & $200<<=300$ & - & 11.0008 & $0.5 x$ \\
\hline 運输倉庫施設 & 住居地域 & 工業系用途地域 & 14 & 15 & 0.5762 & $300<<=400$ & - & 9.6164 & $1.0 \%$ \\
\hline
\end{tabular}


が読み取れる。住居系用途地域内や商業系用途地域 内で建築されるアパートやマンションよりも大規模 な官舎や工場の寄宿舎などが、工業系用途地域内に は多数建築されているためと考えられる。

次に高度地区について検討しよう。千葉県の第 1 種高度地区と第 2 種高度地区内では、建筑物の高さ はそれぞれ図1に示す斜線の高さ以下でなけれぱな らないこととされている。敷地を南北に長くすれば するほど、より高い建築物を建築して、土地を有効 に利用することができる。高度地区を指定する目的 は、第一に北側の隣地の日照を確保しながら、第二 に敷地の共同化を誘導して土地利用の增進を図るこ とにある。第1種高度地区は第 2 種高度地区よりも 建築物の高さの最高限度を低く定めていることから、 第 1 種高度地区は第一の目的に重点を置き、第 2 種 高度地区は第二の目的に重点を置いているというこ

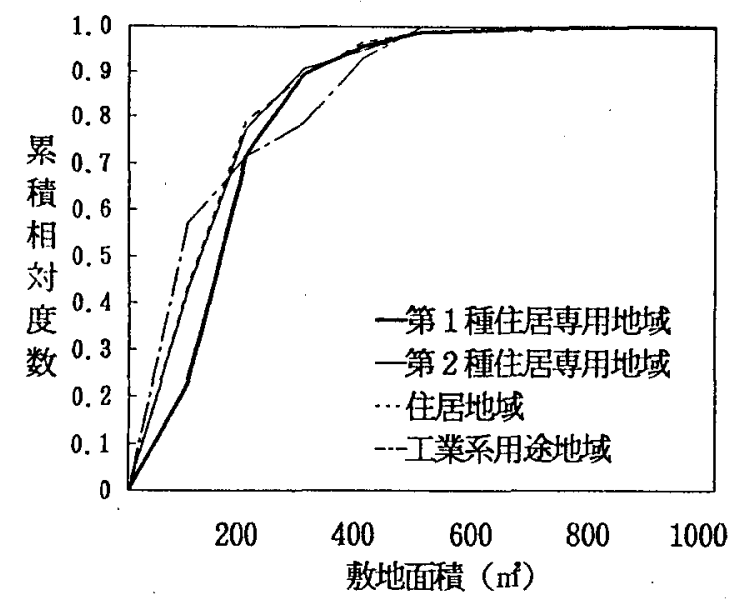

図 3 用途地域別の住宅の敷地面積の累積相対度数分布

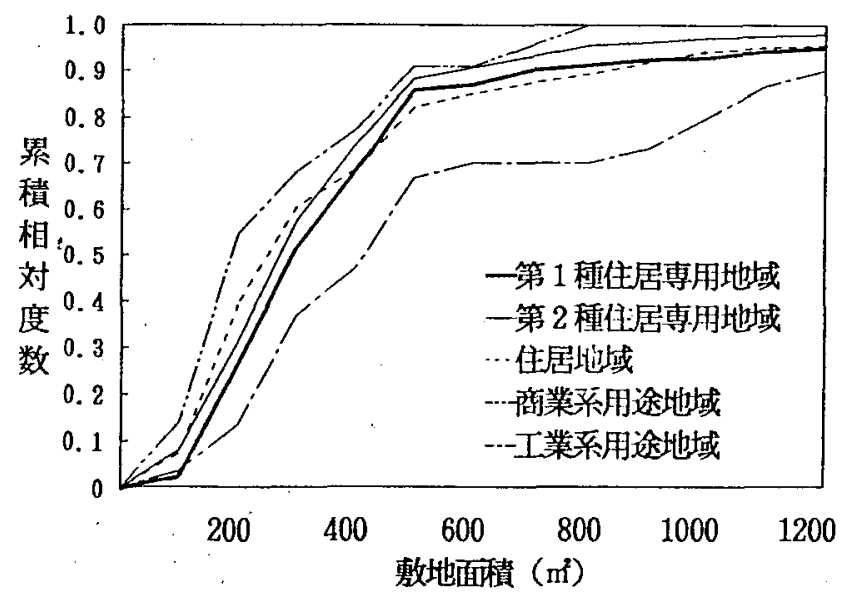

図 4 用途地域別の共同住宅の敷地面積の累積相対度数分布
とができる。表 3 及び図 6 に示したように、高度地 区毎の敷地面積の累積相対度数の有意な差は共同住 宅のみに見られ、片側検定の仮説が有意水準 $2.0 \%$ で呆却され、第 2 種高度地区の敷地面積のほうが第 1 種高度地区のそれよりも大きいと考えられた。こ のことから制度上期待されるとおり、共同住宅に対 しては第 2 種高度地区の敷地の共同化の誘導効果ほ うが第 1 種高度地区のそれよりも大きいと考えられ る。また、敷地が南北に短いときには、高度地区の 斜線制限よりも道路斜線制限のほうが厳しくなるた め、小さい面積の敷地では高度地区の斜線制限が適 用されず、道路斜線制限が適用されることが多い。 このために敷地面積の比較的広い共同住宅でのみ高 度地区に関して有意な差が生じたと思われる。今後、 道路斜線制限を含めた分析により、高度地区や道路 斜楾制限が敷地面積に与える影響をより詳細に検討

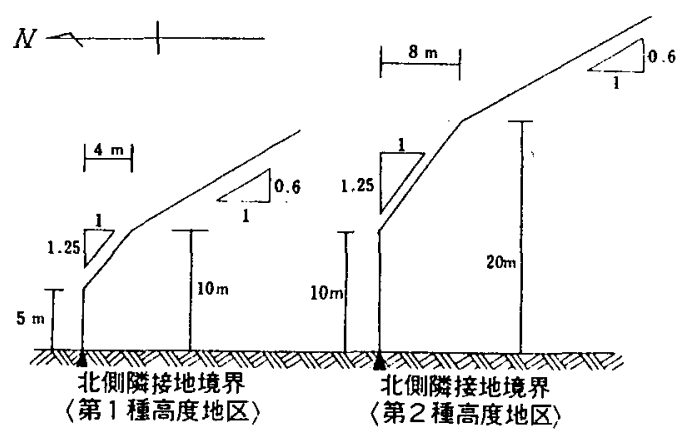

図 5 千葉県における高度地区による建築物の高さの制限

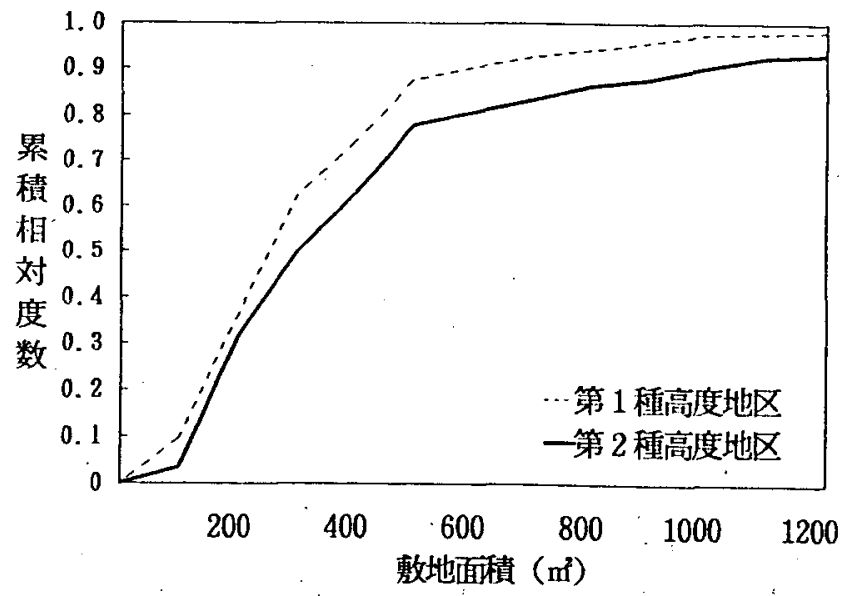

. 図 6 高度地区別の共同住宅の敷地面積の累積相対度数分 
する必要がある。

\section{5. 最奇り駅までの距離が敷地面積に与える影響}

地域地区のみでなく、都市基盤施設も敷地面積に 影響を与えていると予想される。この節では最寄り 駅までの距離が敷地面積に与える影響を検討する。

最寄り駅までの距離の平均値、標準偏差を建筑物 主要用途別に表 4 に示す。表 4 に示した建築物主要

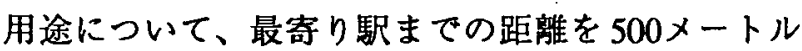
毎に区切って度数分布を調べたところ、いずれも単 峰性の分布を示していた。しかし、この度数分布か ら仮説「最寄り駅までの距離の分布は正規分布に従 う。」についてカイ 2 乗適合度検定を行ったところ、 有意水準 $5 \%$ で仮説を棄却できなかった建築物主要 用途は運輸倉庫施設のみであった。

次に最寄り駅までの距離と敷地面積との相関係数 を建築物主要用途別に算出した結果を表 5 に示す。 ここで、最寄り駅までの距離の単位はメートル、敷 地面積の単位は平方メートルである。表 5 の相関係 数からは、住宅、併用住宅 2 、商業施設にはほとん ど相関がないと考えられる(2)。

\section{6. 敷地面積を外的基準とした数量化 I類分析}

次に敷地面積を外的基準とした数量化 I 類分析を 行うことによって、地域地区や都市基盤施設が敷地 面積に与える影響の寄与を検討した（表 6 ）。用途 地域、高度地区、風致地区、宅地造成工事規制区域 土地区画整理事業施行区域、最寄り駅までの距離を アイテムとして採用した(3)。ただし、風致地区内
の度数がないため、業務施設及び商業施設について は風致地区をアイテムとして採用できなかった。

業務施設や商業施設では重相関係数が高かった。 これらの施設では、特に用途地域や高度地区のレイ ンジや偏相関係数が高く、敷地面積への影響の寄与 が大きい。しかし、住宅や共同住宅では重相関係数 が低く、予測が良くなかった。ここでアイテムとし て採用していない相続時の土地の大きさや個人所得 の高低などの個人的要因が、住宅や共同住宅の敷地 面積に大きく寄与していると予想される。

用途地域、高度地区アイテムの各カテゴリーの与 える影響は、第 4 節のコルモゴロフ・スミルノフ検 定において見たとおりである。共同住宅及び併用住 宅 1 の第 1 種住居専用地域の基準化カテゴリー数量、 共同住宅の工業系用途地域の基準化カテゴリー数量、 共同住宅の第 2 種高度地区の基準化カテゴリー数量 が正の值を示している。

風致地区や宅地造成工事規制区域のレインジや偏 相関係数は概して小さく、これらの敷地面積に対す る影響の寄与は小さい。併用共同住宅、併用住宅 1 、 業務施設及び商業施設ではこれらの地域地区内の度 数が少ないことから、これらの地域地区は敷地面積 に影響を与えているというよりも建筑物を新築する 位置に影響を与えていると考えられる。

また、多くの建築物主要用途で、土地区画整理事 業施行済み区域の基準化カテゴリー数量が正の值を 示し、同未施行区域のそれが負の值を示している。 土地区画整理事業により道路等の都市基盤整備を行 うことが敷地の細分化の防止に役立っていると考え
表 4 最寄り駅までの距離距離の統計量 $(\mathrm{m})$

\begin{tabular}{|c|c|c|}
\hline 用途 & 平均値 & 裂準偏差 \\
\hline 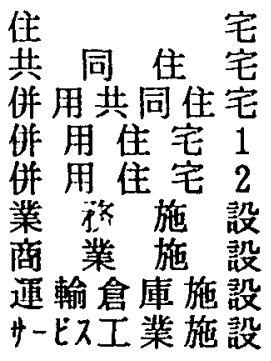 & $\begin{array}{r}1234.4 \\
1004.5 \\
788 . ? \\
1047.8 \\
1267.5 \\
911.5 \\
561.9 \\
1398.9 \\
1210.7\end{array}$ & $\begin{array}{r}693.0 \\
626.8 \\
573.1 \\
656.0 \\
525.3 \\
713.6 \\
435.0 \\
1010.5 \\
729.3\end{array}$ \\
\hline
\end{tabular}

表 5 最寄り駅までの距離 $(\mathrm{m})$ と敷地面積 $(\mathrm{m} 2)$ との相関

\begin{tabular}{|c|c|c|c|c|c|}
\hline 建築物主要用途 & 度数 & $\mathrm{y}$ 切片 & $\mathrm{x}$ 係数 & 相関係数 & 寄与率 \\
\hline & 2025 & 176.6 & -0.007 & -0.030 & 0.001 \\
\hline 基 & 905 & 325.3 & 0.077 & 0.099 & 0.010 \\
\hline 作用共同住宅 & 119 & 298.6 & 0.120 & 0.170 & 0.029 \\
\hline 作雷住宅 1 & 156 & 95.6 & 0.097 & 0.275 & 0.075 \\
\hline 併朋住宅 2 & 12 & 291.8 & -0.025 & -0.054 & 0.003 \\
\hline 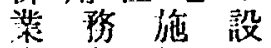 & 64 & 161.6 & 0.290 & 0.347 & 0.121 \\
\hline 商 業 施 設 & 59 & 2091.3 & -0.670 & -0.028 & 0.001 \\
\hline 運輸倉庫施没 & 38 & 383.3 & 0.888 & 0.287 & 0.082 \\
\hline サ-Eス工業施設 & 13 & -72.6 & 0.779 & 0.786 & 0.617 \\
\hline
\end{tabular}


表 6 数量化 I 類分析結果

\begin{tabular}{|c|c|c|c|c|c|c|c|c|c|c|c|c|c|}
\hline \multirow{2}{*}{$\begin{array}{l}T \\
\frac{1}{T} \\
厶\end{array}$} & \multirow[b]{2}{*}{ カテゴリー } & 住 宅 & \multicolumn{3}{|c|}{ 共同住宅 } & \multicolumn{3}{|c|}{ 併用共同住宅 } & \multicolumn{2}{|c|}{ 併用住宅 1} & \multicolumn{2}{|c|}{ 業邪施設 } & 商業施設 \\
\hline & & 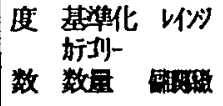 & 度 & $\begin{array}{l}\text { 基準化 } \\
\text { 的扩- } \\
\text { 教昜 }\end{array}$ & レ似 & 度 & 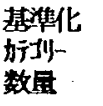 & 以价 & 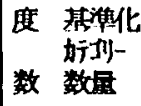 & 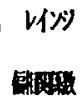 & $\begin{array}{ll}\text { 度 } & \text { 基潐化 } \\
\text { 幵打- } \\
\text { 数 }\end{array}$ & 烨州 & 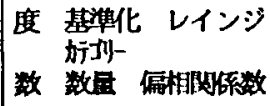 \\
\hline 用 & 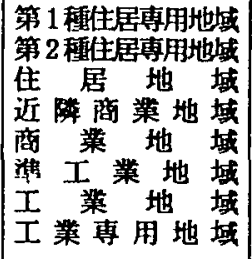 & $\begin{array}{rrr}1231 & -1.2 & \\
323 & 3.0 & \\
408 & 4.5 & 89.2 \\
41 & -18.8 & \\
8 & -60.8 & \\
6 & 28.4 & 0.034 \\
8 & -26.3 & \\
0 & & \end{array}$ & $\begin{array}{r}259 \\
286 \\
308 \\
20 \\
2 \\
15 \\
15 \\
0\end{array}$ & $\begin{array}{r}83.3 \\
-77.7 \\
-3.0 \\
-136.0 \\
-20.0 \\
31.0 \\
257.6\end{array}$ & 0.137 & $\begin{array}{r}9 \\
31 \\
58 \\
11 \\
5 \\
1 \\
4 \\
0\end{array}$ & $\begin{array}{r}-206.0 \\
-135.3 \\
58.1 \\
84.0 \\
92.1 \\
32.0 \\
316.1\end{array}$ & 0.296 & $\begin{array}{rr}52 & 57.2 \\
38 & -72.5 \\
42 & -2.3 \\
17 & 15.4 \\
5 & -61.1 \\
1 & -87.7 \\
1 & 9.3 \\
0 & \end{array}$ & 0.177 & $\begin{array}{rr}3 & -804.6 \\
9 & -44.4 \\
24 & 145.6 \\
11 & -348.0 \\
6 & -675.7 \\
2 & 363.6 \\
7 & 1072.3 \\
2 & -515.8\end{array}$ & 1876.9 & $\begin{array}{rrr}0 & & \\
3 & 6055.9 & \\
14 & 1281.6 & 32454.1 \\
5 & 15635.6 & \\
14 & 17062.6 & \\
1 & -14552.4 & 0.662 \\
22 & -15391.5 & \\
0 & & \end{array}$ \\
\hline 高 & $\begin{array}{l}\text { 第 } 1 \text { 種高度地区 } \\
\text { 第 } 2 \text { 種高度地区 } \\
\text { 高度地区指定外 }\end{array}$ & $\begin{array}{rrr}574 & -16.6 & 24.2 \\
195 & -0.1 & \\
1256 & 7.6 & 0.061\end{array}$ & $\begin{array}{l}408 \\
227 \\
270\end{array}$ & $\begin{array}{l}-38.3 \\
114.7 \\
-38.6\end{array}$ & 0.135 & $\begin{array}{l}47 \\
53 \\
19\end{array}$ & $\begin{array}{r}25.9 \\
-68.5 \\
127.0\end{array}$ & $\begin{array}{l}195.5 \\
0.182\end{array}$ & $\begin{array}{rr}61 & 34.9 \\
30 & -19.9 \\
65 & -23.5\end{array}$ & $\begin{array}{r}58.4 \\
0.104\end{array}$ & $\begin{array}{rr}16 & -174.3 \\
29 & -293.0 \\
19 & 594.0\end{array}$ & 887.0 & $\begin{array}{rrr}11 & -14618.3 & 215421 \\
30 & 1205.7 & \\
18 & 6923.8 & 0.545\end{array}$ \\
\hline 圂 & 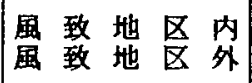 & $\begin{array}{rrr}392 & 35.3 & 43.8 \\
1633 & -8.5 & 0.093\end{array}$ & $\begin{array}{r}60 \\
845\end{array}$ & $\begin{array}{r}-61.3 \\
4.4\end{array}$ & $\begin{array}{r}65.7 \\
0.028\end{array}$ & $\begin{array}{r}3 \\
116\end{array}$ & $\begin{array}{r}-208.6 \\
5.4\end{array}$ & $\begin{array}{l}214.0 \\
0.090\end{array}$ & $\begin{array}{rr}12 & -6.6 \\
144 & 0.5\end{array}$ & $\begin{array}{r}7.1 \\
0.007\end{array}$ & $\begin{array}{r}0 \\
64\end{array}$ & & $\begin{array}{r}0 \\
59\end{array}$ \\
\hline 宅 & 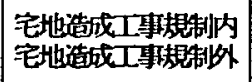 & $\begin{array}{rrr}624 & -2.3 & 3.3 \\
140: & 1.0 & 0.008\end{array}$ & $\begin{array}{l}106 \\
799\end{array}$ & $\begin{array}{r}-16.0 \\
21\end{array}$ & $\begin{array}{r}18.1 \\
0.010\end{array}$ & $\begin{array}{r}8 \\
111\end{array}$ & $\begin{array}{l}384.4 \\
-27.7\end{array}$ & $\begin{array}{l}4121 \\
0.247\end{array}$ & $\begin{array}{rr}23 & -69.1 \\
133 & 11.9\end{array}$ & $\begin{array}{r}81.0 \\
0.114\end{array}$ & $\begin{array}{rr}2 & 290.1 \\
62 & -9.4\end{array}$ & $\begin{array}{l}299.5 \\
0.120\end{array}$ & $\begin{array}{rrr}2 & -700.2 & 724.8 \\
57 & 24.6 & 0.016\end{array}$ \\
\hline B & 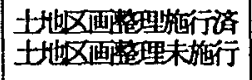 & $\begin{array}{rrr}200 & 8.2 & 9.6 \\
1730 & -1.4 & 0.022\end{array}$ & $\begin{array}{l}345 \\
560\end{array}$ & $\begin{array}{r}25.7 \\
-15.8\end{array}$ & $\begin{array}{r}41.5 \\
0.039\end{array}$ & 8 & $\begin{array}{r}142.1 \\
-135.1\end{array}$ & $\begin{array}{l}277.2 \\
0.342\end{array}$ & $\begin{array}{rr}48 & -6.3 \\
108 & 2.8\end{array}$ & $\begin{array}{r}9.1 \\
0.019\end{array}$ & $\begin{array}{rr}23 & 150.7 \\
41 & -84.5\end{array}$ & $\begin{array}{l}235.2 \\
0.242\end{array}$ & $\begin{array}{rrr}21 & -3959.6 & 6147.8 \\
38 & 2188.2 & 0.307\end{array}$ \\
\hline 駅 & $\begin{array}{l}250 x-ト ル 以 下 \\
850 x-ト ル 以 下 \\
1450 x-ト ル 以 下 \\
2050 x-ト ル 以 下 \\
2050 x-ト ル 1 \\
\end{array}$ & $\begin{array}{rrr}76 & 66.4 & \\
618 & 16.7 & 84.7 \\
589 & -18.3 & \\
462 & -5.4 & 0.119 \\
280 & -7.6 & \end{array}$ & $\begin{array}{r}33 \\
416 \\
262 \\
111 \\
83\end{array}$ & $\begin{array}{r}-163.0 \\
6.0 \\
-48.3 \\
-13.6 \\
205.1\end{array}$ & $\begin{array}{l}3681 \\
0.152\end{array}$ & $\begin{array}{r}13 \\
67 \\
25 \\
7 \\
7\end{array}$ & $\begin{array}{r}-210.1 \\
-44.4 \\
-8.2 \\
798.8 \\
45.8\end{array}$ & 0.502 & $\begin{array}{lr}15 & -34.8 \\
50 & -28.5 \\
51 & 9.4 \\
27 & -50.6 \\
13 & 218.1\end{array}$ & $\begin{array}{l}268.7 \\
0.298\end{array}$ & $\begin{array}{rr}10 & -164.9 \\
24 & 56.6 \\
16 & -119.7 \\
10 & -17.3 \\
4 & 594.3\end{array}$ & $\begin{array}{l}759.2 \\
0.380\end{array}$ & $\begin{array}{rrr}20 & -20708.1 & \\
29 & 10538.3 & 32116.2 \\
7 & 11408.1 & \\
3 & 9564.9 & 0.647 \\
0 & & \end{array}$ \\
\hline & 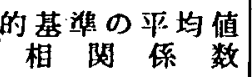 & $\begin{array}{l}168.1 \\
0.168\end{array}$ & & $\begin{array}{l}403.0 \\
0.238\end{array}$ & & & $\begin{array}{l}393.3 \\
0.572\end{array}$ & & $\begin{array}{l}196.8 \\
0.371\end{array}$ & & & & $\begin{array}{r}1715.0 \\
0.686\end{array}$ \\
\hline
\end{tabular}

られる。しかし、商業施設では逆に未施行区域の基 準化カテゴリー数量が正の值を示している。開発行 為等の手段により自らの手で区画の変更や土地の開 発を行う大規模商業施設の存在が一因と思われる。

次に最寄り駅までの距離が敷地面積に与える影響 について検討しよう。第 5 節において最奇り駅まで の距離と商業施設の敷地面積とはほほ無相関と考え られたが、ここでは用途地域や高度地区の影響を取 ク除いた偏相関係数がやや高い值を示している。こ のことから、第 5 節において最奇り駅までの距離と 商業施設の敷地面積とがほほ無相関と考えられた第 一の原因として、商業施設の敷地面積に対して用途 地域や高度地区の影響の寄与が大きいことが考えら れる。また、商業施設では最寄り駅までの距離が大 きくなるにつれて基準化カテゴリー数量も大きくな り、最奇り駅までの距離が最大のカテゴリーで基準 化カテゴリー数量が減少に転じている(4)。このこと から、第 5 節において最寄り駅までの距離と商業施
設の敷地面積とがほほ無相関と考えられた第二の原 因として、数量化 I 類分析により地域地区の影響を 取り除いても、基準化カテゴリー数量が最寄り駅ま での距離に対して単調増加性を有しないことが考え られる。最寄り駅までの距離をどのような間隔区分 でカテゴリー化するかについて分析者の恣意性も残 されており(5)、今後、地域地区の影䉪を取り除きな がら、分析者の恣意がはいらないように、都市基盤 施設が建築物の敷地面積に与える影響をより詳細に 分析できるよう、分析法を検討する必要がある。

\section{7. 本稿の成果と残された課題}

本稿では、新築の建築物の敷地面積に与える要因 を建築物主要用途別に検討した。まず、建築物主要 用途別に検討結果をまとめてみよう。

住宅については次の結果が得られた。敷地面積を 外的基準とする数量化 I 類分析では、予測が良くな 
く、アイテムとして採用していない個人的要因の影 響の寄与が大きいと考えられた。しかし、コルモゴ ロフ・スミルノフ検定の結果からは、面積 100 平方 メートル以下の狭小な敷地の相対度数が第 1 種住居 専用地域内で少ないことが明らかとなった。また、 対数正規分布への適合性の検討結果から、住宅が新 築される際に敷地の細分化が進んでいる可能性が示 された。既存と新築の住宅の敷地面皘をより詳細に 分析することが今後の課題として残された。

商業施設については、次の結果が得られた。敷地 面積が 150平方メートルから 350 平方メートルを中 心に度数が集中している反面、ごく少数の大規模な 敷地を有する施設が建築確認申請されていた。地域 地区や最寄り駅までの距離をアイテムとし、敷地面 積を外的基準とする数量化 I 類分析では、予測が良 いことが明らかになった。

次に、地域地区や都市基盤施設が敷地面積に与え る影響という点から検討結果をまとめてみよう。コ ルモゴロフ・スミルノフ検定の結果、第 1 種住居専 用地域内の住宅や併用住宅 1 には面積 100 平方メー トル以下の狭小な敷地の相対度数が少なかった。ま た、制度上期待されるとおり、共同住宅に対しては 第 2 種高度地区の敷地の共同化の誘導効果ほうが第 1 種高度地区のそれよりも大きいと考えられた。今 後、道路斜線制限を含めた分析により、高度地区や 道路斜線制限が敷地面積に与える影響をより詳細に 検討することが課題として残された。数量化 I 類分 析の結果からは、風致地区や宅地造成工事規制区域 は敷地面積に影響を与えているというょりも建筑物 を新筑する位置に影響を与えていると考えられた。 また、最寄り駅までの距離が敷地面積に与える影響 をより詳細に分析するには、分析方法に工夫が必要 であるとの課題が残された。

さらに今後、用途地域や地区計画で敷地面積の最 低限度を決定する際に、他の地域地区による制限を どのように組み合わせると有効であるか、どのよう な建築物主要用途に有効であるかを検討し、その決 定に関する明確で定量的な基準の作成を検討したい。

\section{(補注)}

1）個人情報の保護のため、度数10以上の建築物主 要用途についての集計結果のみ表 1 に掲載した。

2）母集団における敷地面積の分布が正規分布であ るとは第 3 節の結果から考えにくいこと、また、運 輸倉庫施設を除いて最寄り駅までの距離の分布が正 規分布に従うと考えられないことから、母集団にお ける相関係数に関する $\mathrm{t}$ 検定を行うのは不適当と考 えた。

3）防火地域・準防火地域をアイテムとすることが できなかった。なぜなら、用途地域が商業地域又は 近隣商業地域内であり、かつ高度地区指定なしの区 域は、必ず防火地域又は準防火地域に該当するため、 次元が退化するからである。

4）最寄り駅までの距離の偏相関係数が高かった併 用共同住宅においても、同様の傾向が見られる。

5) 本稿の表 6 の数量化 I 類分析で、最寄り駅まで の距離の間隔区分は、次の方法により決定された。 第 5 節で調査された最寄り駅までの距離の平均值と 標準偏差から、平均値土標準偏差 $\times 0.5$ 、平均値士 標準偏差 $\times 1.5$ となる付近で区切りのよい数值を間 隔区分とした。しかし、表 4 に示したように、建物 主要用途每にその平均值や標準偏差が異なるため、 必ずしも1450メートル以下のカテゴリーで度数が最 大になっているとは限らない。

\section{参考文献}

石坂公一(1984)首都圈における住宅の敷地規模分布 の特性について「別冊都市計画」,19,457-462

大場亨、田草川信慈、鈴木義昌(1994)地域地区や都 市基盤施設が敷地面積に与える影響の分析,地 理情報システム学会講演諭文集」,3,73-78

K.M.マニルザマン、浅見泰司、岡部篤行(1994)東京 都世田谷区における画地の土地利用とその形状 に関する研究，「GIS-理論と応用」,2,83-90

横屋克昌、光吉健次、萩島哲、金南 =(1984)新築建 築物の立地動向からみた用途地域指定の効果に 関する研究,「別冊都市計画」,19,427-432 